\title{
Methodology for assessing the effectiveness of innovative development of personnel in the agro-industrial complex
}

\author{
G.Y Khodjamuratova*, and D.I. Vafoeva \\ Tashkent State University of Economics, 100003, Tashkent, Uzbekistan
}

\begin{abstract}
In the article developed a system of indicators that characterize the intensive development of trends and factors in the development of personnel of agricultural enterprises, on the basis of which the level of innovative development is assessed. The author identified the strengths and weaknesses of agro-industrial complex enterprises on the basis of a SWOT analysis, based on the results of the analysis, the main directions for improving the efficiency of personnel management at the selected enterprises were determined.
\end{abstract}

\section{Introduction}

One of the main conditions in determining the direction of improving the effectiveness of personnel management in agro-industrial enterprises is to identify their strengths and weaknesses through the analysis of the internal environment, as well as opportunities and threats through the analysis of the external environment. SWOT-analysis allows to carry out the analysis of the external environment, to assess the competitive situation in the market, to have a clear idea of the advantages and disadvantages of the enterprise. The results of the analysis will help to choose the direction of development of the enterprise, use its strengths, take into account its weaknesses and take measures to eliminate them, as well as use the opportunities provided by the market and avoid various threats and challenges. serves to identify goals [1].

The purpose of the research is to develop and improve the Methodology for assessing the effectiveness of innovative development of personnel in the agro-industrial complex.

Research objectives:

- Identification of strengths and weaknesses of Gulistan Extract Oil JSC;

- Identification of opportunities and threats of Gulistan Extract Oil JSC;

- Identification of opportunities and threats of JSC "Yangiyul Yog-Moy";

- Identify the strengths and weaknesses of JSC "Yangiyul Yog-Moy".

Research methods:

In the process of preparing the dissertation, such methods as general scientific, formallogical, specific methods of studying the situation, classification, generalization,

\footnotetext{
*Corresponding author: gulbakhor1963@mail.ru
} 
horizontal and vertical comparison, econometric modeling, empirical research, factor analysis, forecasting were used.

\section{Research results:}

The results of the assessment of the factors (strengths and weaknesses) that characterize the internal state of the enterprise and the factors of market conditions (opportunities and threats) are categorized and compared to develop their fair interpretation and strategic directions in the field of domestic and foreign policy.

We can observe a negative competitive situation for the enterprises under study, i.e. the strengths of the enterprises as a whole cannot create a competitive advantage for them. Compared to Gulistan Extract Oil JSC, Yangiyul Yog-Moy's strengths are 0.03 points higher, and its weaknesses are 0.03 points higher, which reflects the balance of strengths and weaknesses.

\section{Literature review:}

The issues of management, specialization, and optimization of production capacities are reflected in the scientific works of the following foreign scientists: W. Cline [2], C.G. Doeringer and K.G. Dickerson [3], Goldratt E. M. [4], J. Lee [6], C. Forza [5] and F. Salvador and others. A significant contribution to the development of the theory and practice of production capacity management was made by economists from the CIS countries. Aspects of the organization of the use of production capacity in industrial enterprises and its management were studied by Russian scientists K.S. Krivyakin [7].

\section{Materials and methods}

Today, there are many ways to perform SWOT analysis, which serves as the basis of strategic planning. This creates a wide range of opportunities for enterprises to develop options for strategic activities in the market. SWOT-analysis is a convenient tool that provides structural illumination of the characteristics of the enterprise and the environment. When using this or that method of conducting SWOT-analysis, the general scheme of this process remains unchanged, but the number of factors can be very large. This necessitates the use of special methods for their stratification. At the same time, it is important to take into account the subjective factors identified by the participants in the analysis of the process [8-9].

For the SWOT-analysis, a questionnaire was developed based on the evaluation indicators of the enterprises surveyed, as well as a convenient method that allows to take full account of the various factors that most affect the activities of agro-industrial enterprises.

The coefficient of significance of the factors was determined by us using the following formula:

$$
\mathrm{K}_{\mathrm{ij}}=\sum_{i=1}^{n} x i: \sum_{j=1}^{n} x j
$$

$\mathrm{K}_{\mathrm{ij}}$ - significance coefficient;

$x_{i}$ - the number of factors that characterize the parameters specified by the experts;

$x_{j}$ - the total number of factors that characterize the parameters.

The higher the materiality index, the more important this parameter is for the enterprise.

According to the results of the survey, the SWOT-analysis of staffing of JSC "Gulistan extract oil" and JSC "Yangiyul Yog-Moy" agro-industrial enterprises revealed their strengths and weaknesses (tables-1,2,3). 
Table 1. Identification of strengths and weaknesses of Gulistan Extract Oil JSC

\begin{tabular}{|c|c|c|}
\hline $\begin{array}{l}\text { Evaluation } \\
\text { parameters }\end{array}$ & Strengths & Weaknesses \\
\hline 1. Organizational & $\begin{array}{l}\text { Employees' interest in the } \\
\text { development of the enterprise, } \\
\text { the establishment of a high } \\
\text { level of communication } \\
\text { between departments }\end{array}$ & $\begin{array}{l}\text { Low level of staff skills, slow } \\
\text { adaptation to changes in the } \\
\text { external environment and non- } \\
\text { standard conditions, high level } \\
\text { of dissatisfaction }\end{array}$ \\
\hline Coefficient & 0,65 & 0,35 \\
\hline $\begin{array}{l}\text { 2. Motivation of } \\
\text { employees }\end{array}$ & $\begin{array}{l}\text { Regular awarding of prizes } \\
\text { on holidays at the enterprise }\end{array}$ & $\begin{array}{c}\text { Lack of strong personnel policy } \\
\text { against competitors, low level } \\
\text { of motivation }\end{array}$ \\
\hline Coefficient & 0,36 & 0,64 \\
\hline $\begin{array}{l}\text { 3. Corporate spirit } \\
\text { in the enterprise }\end{array}$ & $\begin{array}{l}\text { Organization of corporate } \\
\text { meetings at the enterprise }\end{array}$ & $\begin{array}{c}\text { Lack of development of } \\
\text { corporate culture in the } \\
\text { enterprise }\end{array}$ \\
\hline Coefficient & 0,45 & 0,55 \\
\hline $\begin{array}{l}\text { 4. Qualifications of } \\
\text { leaders }\end{array}$ & $\begin{array}{l}\text { Specialization of managers in } \\
\text { the field }\end{array}$ & Dissatisfaction of leaders \\
\hline Coefficient & 0,40 & 0,60 \\
\hline $\begin{array}{l}\text { 5. Innovative } \\
\text { processes in the } \\
\text { enterprise }\end{array}$ & $\begin{array}{l}\text { Organization of the } \\
\text { innovation process in the } \\
\text { enterprise }\end{array}$ & $\begin{array}{l}\text { High costs for research and } \\
\text { long payback period }\end{array}$ \\
\hline Coefficient & 0,14 & 0,86 \\
\hline
\end{tabular}

Source: Based on the results of a survey conducted by Guliston Extract Oil JSC

According to the research, the strengths of JSC "Gulistan Extract Oil" are the interest of employees in the development of the enterprise, the high level of communication between departments (coefficient 0.65), the weakest point is the high cost of research and long payback period. (coefficient of 0.86).

Another strength of Gulistan Extract Oil JSC is the organization of corporate meetings (coefficient 0.45 ), the weak side is the lack of strong personnel policy against competitors, low level of employee motivation (coefficient 0.64).

Table 2. Identify the strengths and weaknesses of JSC "Yangiyul Yog-Moy".

\begin{tabular}{|c|c|c|}
\hline $\begin{array}{l}\text { Evaluation } \\
\text { parameters }\end{array}$ & Strengths & Weaknesses \\
\hline 1. Organizational & $\begin{array}{l}\text { Employees' interest in the } \\
\text { development of the enterprise, } \\
\text { the establishment of a high } \\
\text { level of communication } \\
\text { between departments }\end{array}$ & $\begin{array}{l}\text { Low level of staff skills, slow } \\
\text { adaptation to changes in the } \\
\text { external environment and non- } \\
\text { standard conditions, high level } \\
\text { of dissatisfaction }\end{array}$ \\
\hline Coefficient & 0,59 & 0,41 \\
\hline $\begin{array}{l}\text { 2. Motivation of } \\
\text { employees }\end{array}$ & $\begin{array}{l}\text { Regular awarding of prizes on } \\
\text { holidays at the enterprise }\end{array}$ & $\begin{array}{c}\text { Lack of strong personnel policy } \\
\text { against competitors, low level } \\
\text { of motivation }\end{array}$ \\
\hline Coefficient & 0,38 & 0,62 \\
\hline $\begin{array}{l}\text { 3. Corporate } \\
\text { spirit in the } \\
\text { enterprise }\end{array}$ & $\begin{array}{l}\text { Organization of corporate } \\
\text { meetings at the enterprise }\end{array}$ & $\begin{array}{l}\text { Lack of development of } \\
\text { corporate culture in the } \\
\text { enterprise }\end{array}$ \\
\hline Coefficient & 0,61 & 0,39 \\
\hline $\begin{array}{l}\text { 4. Qualifications } \\
\text { of leaders }\end{array}$ & $\begin{array}{c}\text { Specialization of managers in } \\
\text { the field }\end{array}$ & Dissatisfaction of leaders \\
\hline Coefficient & 0,42 & 0,58 \\
\hline 5. Innovative & Organization of the & High costs for research and long \\
\hline
\end{tabular}




\begin{tabular}{|c|c|c|}
\hline $\begin{array}{l}\text { processes in the } \\
\text { enterprise }\end{array}$ & $\begin{array}{c}\text { innovation process in the } \\
\text { enterprise }\end{array}$ & payback period \\
\hline Coefficient & 0,15 & 0,85 \\
\hline
\end{tabular}

Source: Based on the results of a survey conducted by JSC "Yangiyul Yag-Moy"

The strength of Yangiyul Yog-Moy JSC is the organization of corporate meetings at the enterprise, including the organization of free lunches for employees at the enterprise (coefficient 0.61), the weakness is the slowness of innovative processes at the enterprise (coefficient 0.85). .

Each of the parameters for assessing the external environment is considered in terms of opportunities and threats for the enterprises of JSC "Gulistan extract oil" and JSC "Yangiyul Yog-Moy" (Tables 3, 4).

Table 3. Identification of opportunities and threats of Gulistan Extract Oil JSC.

\begin{tabular}{|c|c|c|}
\hline $\begin{array}{c}\text { Evaluation } \\
\text { Parameters }\end{array}$ & $\begin{array}{c}\text { Evaluation } \\
\text { Parameters }\end{array}$ & Threats \\
\hline 1. Demand & $\begin{array}{c}\text { High market capacity, high market } \\
\text { growth rates }\end{array}$ & Market growth rates \\
\hline Coefficient & 0,65 & 0,35 \\
\hline 2. Competition & $\begin{array}{c}\text { Lack of substitute goods in the } \\
\text { market, the monopoly position of } \\
\text { the enterprise }\end{array}$ & $\begin{array}{c}\text { Large number of external (foreign) } \\
\text { competitors, low prices for (foreign) } \\
\text { competitors' goods }\end{array}$ \\
\hline Coefficient & 0,49 & 0,51 \\
\hline management & $\begin{array}{c}\text { Introduction of modern personnel } \\
\text { management systems (HR) with in- } \\
\text { depth study of advanced foreign } \\
\text { experience }\end{array}$ & $\begin{array}{c}\text { Introduction of modern personnel } \\
\text { management systems (HR) in foreign } \\
\text { enterprises and joint ventures }\end{array}$ \\
\hline Coefficient & 0,73 & 0,27 \\
\hline 4. Science and & $\begin{array}{c}\text { Introduction of new technologies, } \\
\text { technology }\end{array}$ & $\begin{array}{c}\text { Rapid development of science and } \\
\text { technology in the context of } \\
\text { globalization }\end{array}$ \\
\hline Coefficient & enterprise & 0,22 \\
\hline 5. Society & $\begin{array}{c}\text { Consumer culture and traditions in } \\
\text { the process of cooking (national } \\
\text { recipes) }\end{array}$ & $\begin{array}{c}\text { The development of fast food } \\
\text { consumption }\end{array}$ \\
\hline Coefficient & 0,45 & 0,55 \\
\hline
\end{tabular}

Source: Based on the results of a survey conducted by Guliston Extract Oil JSC.

High market capacity, high market growth rates and the ability to introduce modern personnel management systems (HR) with in-depth study of advanced foreign experience (coefficients 0.85 and 0.73 , respectively) play a leading role in the development of JSC "Gulistan Extract Oil". The biggest threats are the large number of external (foreign) competitors, low prices for (foreign) competitors' goods and the development of fast food consumption in the regions (coefficients 0.71 and 0.55 , respectively).

Table 4. Identification of opportunities and threats of JSC "Yangiyul Yog-Moy".

\begin{tabular}{|c|c|c|}
\hline $\begin{array}{l}\text { Evaluation } \\
\text { Parameters }\end{array}$ & Opportunities & Threats \\
\hline 1. Demand & $\begin{array}{l}\text { High market capacity, high } \\
\text { market growth rates }\end{array}$ & Market growth rates \\
\hline Coefficient & 0,67 & 0,33 \\
\hline 2. Competition & $\begin{array}{l}\text { Lack of substitute goods in } \\
\text { the market, the monopoly } \\
\text { position of the enterprise }\end{array}$ & $\begin{array}{l}\text { Large number of external } \\
\text { (foreign) competitors, low } \\
\text { prices for (foreign) } \\
\text { competitors' goods }\end{array}$ \\
\hline
\end{tabular}




\begin{tabular}{|l|c|c|}
\hline Coefficient & 0,34 & 0,66 \\
\hline management & $\begin{array}{c}\text { Introduction of modern } \\
\text { personnel management } \\
\text { systems (HR) with in-depth } \\
\text { study of advanced foreign } \\
\text { experience }\end{array}$ & $\begin{array}{c}\text { Introduction of modern } \\
\text { personnel management } \\
\text { systems (HR) in foreign } \\
\text { enterprises and joint ventures }\end{array}$ \\
\hline Coefficient & 0,71 & 0,29 \\
\hline $\begin{array}{l}\text { 4. Science and } \\
\text { technology }\end{array}$ & $\begin{array}{c}\text { Introduction of new } \\
\text { technologies, support of } \\
\text { research work by the } \\
\text { enterprise }\end{array}$ & $\begin{array}{c}\text { Rapid development of science } \\
\text { and technology in the context } \\
\text { of globalization }\end{array}$ \\
\hline Coefficient & 0,88 & 0,12 \\
\hline 5. Society & $\begin{array}{c}\text { Consumer culture and } \\
\text { traditions in the process of } \\
\text { cooking (national recipes) }\end{array}$ & $\begin{array}{c}\text { The development of fast food } \\
\text { consumption }\end{array}$ \\
\hline Coefficient & 0,75 & 0,25 \\
\hline
\end{tabular}

Source: Based on the results of a survey conducted by JSC "Yangiyul Yag-Moy".

For JSC "Yangiyul Yog-Moy" there is an opportunity to introduce new technologies, support research work by the company and the introduction of modern personnel management systems (HR) with in-depth study of advanced foreign experience (coefficients 0.88 , respectively). and 0.71). The biggest threats are the large number of external (foreign) competitors, low prices for (foreign) competitors' goods (coefficient $0.76)$.

\section{Results and Discussion}

In short, the interest of employees of JSC "Gulistan Extract Oil" in the development of the enterprise, the high level of communication between departments serves to increase the efficiency of personnel management and leads to a competitive advantage (0.65).

It is expedient for JSC "Yangiyul Yog-Moy" to implement a strategy for the development of motivational system based on the organization of corporate meetings, including the organization of free lunches for employees (coefficient 0.61). The main factor hindering the development of innovative processes at JSC "Yangiyul Yog-Moy" is the poor organization of research and development. The weakness of both companies is their slow pace of innovation.

For ease of description and analysis, we have presented data on the assessment of strengths and weaknesses of enterprises, as well as favorable opportunities and threats in the form of separate tables. Classification of parameters in descending order of significance coefficients shows that in the development of the development of the enterprise, it is necessary to focus primarily on its strengths and weaknesses, as well as opportunities and threats.

In order to articulate the results of the study more clearly and precisely, it is necessary to determine the sum of the individual mean scores for each of the strengths, weaknesses, opportunities, and threats. The maximum value of the strengths and weaknesses of the enterprise is equal to 5 points, i.e. the number of items accepted for evaluation. In this case, the maximum score for each item is 1 point. Similarly, the total assessment value for opportunities and threats is 5 points. The total average score for each area of the SWOT analysis was determined by dividing the total score by the number of items in the area under study.

$$
\mathrm{S}_{\text {mid. }}\left(\mathrm{W}_{\text {mid. }}, \mathrm{O}_{\text {mid. }}, \mathrm{T}_{\text {mid. }}\right)=\sum_{j=1}^{i=1} K i j: \sum_{i=1}^{n} M i
$$


$M_{i}$ - the maximum value of each item;

$\mathrm{n}$ - number of bands.

The average value of benefits for JSC "Gulistan extract oil" (Variety 1) is as follows:

$\mathrm{S}_{\text {mid. }} 1=(0,65+0,36+0,45+0,40+0,14): 5=0,40$

The average value of the defects $\left(\mathrm{W}_{\text {mid. } 1}\right)$ is as follows:

$\mathrm{W}_{\text {mid. }} 1=(0,35+0,64+0,55+0,60+0,86): 5=0,60$

The average value of the capacity $\left(\mathrm{O}_{\text {mid. }} 1\right)$ is as follows:

$\mathrm{O}_{\text {mid. }} 1=(0,65+0,49+0,73+0,78+0,45): 5=0,62$

The average value of threats $\left(\mathrm{T}_{\text {mid. } 1}\right)$ is as follows:

$\mathrm{T}_{\text {mid. }} 1=(0,35+0,51+0,27+0,22+0,55): 5=0,38$

The average evaluation indicators in the areas of SWOT-analysis for JSC "Yangiyul Yog-Moy" are as follows:

$\mathrm{S}_{\text {mid. }} 2=(0,59+0,38+0,61+0,42+0,15): 5=0,43$

$\mathrm{W}_{\text {mid. }} 2=(0,41+0,62+0,39+0,58+0,85): 5=0,57$

$\mathrm{O}_{\text {mid. }} 2=(0,67+0,34+0,71+0,88+0,75): 5=0,67$

$\mathrm{T}_{\text {mid. }} 2=(0,33+0,66+0,29+0,12+0,25): 5=0,33$

The difference in the average coefficients calculated in the areas of "advantages" and "disadvantages" is necessary to assess the level of relative competitiveness of the enterprise, as well as its competitive position. Based on the difference between the average coefficients in the areas of "opportunities" and "threats", it is possible to identify and assess the relative opportunities and threats for the enterprise, as well as for competitors in accordance with the conditions of the external environment.

\section{Conclusions}

The results of the assessment of the factors (strengths and weaknesses) that characterize the internal state of the enterprise and the factors of market conditions (opportunities and threats) are categorized and compared to develop their fair interpretation and strategic directions in the field of domestic and foreign policy.

We can observe a negative competitive situation for the enterprises under study, i.e. the strengths of the enterprises as a whole cannot create a competitive advantage for them. Compared to Gulistan Extract Oil JSC, Yangiyul Yog-Moy's strengths are 0.03 points higher, and its weaknesses are 0.03 points higher, which reflects the balance of strengths and weaknesses.

Based on the results of the analysis, we can draw conclusions about the competitiveness of the potential of enterprises. The superiority factors, which are highly valued by experts, create a solid foundation for the business, at the expense of which competitors cannot break the enterprise. Relatively underestimated advantage factors are internal opportunities to increase competitiveness through activities aimed at strengthening these factors. The lower the rating given, the higher the internal beliefs of competitiveness.

According to the results of the SWOT-analysis, JSC "Gulistan Extract Oil" in its development can be based on the system of employee motivation. Yangiyul Yog-Moy JSC should be based on modern methods of corporate spirit and personnel management.

\section{References}

1. S.Sh. Yusupov, Strategies for the development of textile enterprises in Uzbekistan in a highly competitive environment, Doctor of Philosophy $(\mathrm{PhD})$ dissertation, author's ref, 81 (TSU, 2019) 
2. W. Cline, The future of international trade in textiles and apparel, Institute for International Economics (Washington,1992)

3. C.G. Doeringer, K.G. Dickerson, Textiles and apparel in the global economy (Prentice Hall, New Jersey, 2004)

4. E.M. Goldratt, Late night discussions on the theory of constraints (North River Press, Great Barrington,1983)

5. C. Forza, F. Salvador, Inter. Journal of Production Economics 70, 21-36 (2001)

6. J. Lee, Competitiveness of textile and apparel industries in the United States and Japan (Iowa State University: Iowa, 2013)

7. K. Krivyakin, B. Tursunov, Z. Hakimov, Bulletin of Science and Practice, 4(1), 228$241(2018)$

8. V.I. Nabokov, K.V. Nekrasov, N.K. Yuldashev, B.O. Tursunov, Innovative activity of organizations of the agro-industrial complex, Theory and practice of agricultural management, 343-347 (2019)

9. E.V. Khudyakova, V.T. Vodyannikov, V.E. Berdyshev, N.V. Skorokhodova, Ya.S. Chistova, Agrarian Bulletin of the Urals, Special issue "Economics", 92-100 (2020) DOI: 10.32417/1997-4868-2021-13-92-100 (In Russian) 